\title{
CONVERGÊNCIA DAS ELITES E INOVAÇÕES FINANCEIRAS: \\ a governança corporativa no Brasil*
}

\section{Roberto Grün}

\section{Introdução}

Um dos diagnósticos mais freqüentes a respeito do capitalismo contemporâneo mundial, inclusive o brasileiro, é de que há prevalecência de seu componente financeiro sobre as demais dimensões, principalmente a industrial (Chesnais, 2004). Para expressar essas novas circunstâncias, as visões mais extremas falam em "financeirização" da economia (Orléan, 1999; Froud et al.,

* O texto foi escrito com material produzido em projetos de pesquisa financiados pela Fapesp e pelo CNPq, entidades a quem agradeço pelo apoio. Também agradeço os comentários penetrantes dos pareceristas anônimos da RBCS, que muito contribuíram para as possíveis qualidades dessa versão final do texto.

Artigo recebido em novembro/2004

Aprovado em abril/2005
2000). As finanças levariam de roldão as razões de outra natureza e imporiam ao mundo sua lógica.

De modo geral, este artigo pretende nuançar essa apreciação, mostrando que o que se está rapidamente espalhando é mais a linguagem financeira do que a "financeirização" propriamente dita. Sua proposição é a de que quando os instrumentos de dominação da lógica financeira são acatados pela sociedade, eles sofrem grandes transformações, alterando sensivelmente seu escopo e funcionamento, mas a manutenção da linguagem original, que está previamente legitimada nos opinion makers, produz esse efeito de pensarmos estar diante de uma simples cópia de instrumentos utilizados em outras paragens. E esse processo "ajusta" o uso e o alcance dos instrumentos às necessidades e constrangimentos de diversos grupos sociais, correspondendo a uma versão atual das defesas que a sociedade sempre 
levantou contra a expansão desenfreada da lógica de mercado, descritas classicamente por Polanyi (2001 [1944]). Conseqüentemente, creio que o vaticínio da dominação inexorável das finanças é uma espécie de sociologismo, mais uma manifestação do que Bourdieu (1974) chamava de "fatalismo do provável".

Para demonstrar minhas afirmações, traçarei alguns pontos da evolução da governança corporativa no Brasil, a qual está sendo crescentemente vista como o coroamento de todos os instrumentos pontuais de imposição da lógica financeira nas sociedades modernas. Pretendo mostrar que o blue-print original da governança corporativa, ao se espraiar pelo país, tem-se alterado sensivelmente mediante as interações sociais dos diversos grupos de atores que dela se apropriam. Os grupos que conseguem imprimir a sua marca na governança corporativa brasileira, e assim alterar o seu conteúdo, pertencem às elites nacionais e usam a governança corporativa nas suas estratégias de composição e recomposição de forças no campo do poder. Assim é possível utilizar a difusão da governança corporativa no Brasil para analisar o funcionamento dos grandes circuitos de força que produzem a lógica social da evolução da nossa sociedade. E, de maneira indireta, para mostrar a necessidade de pôr nuanças nos diagnósticos e prognósticos fechados sobre a "financeirização".

A necessidade de expor a lógica dessa síntese dos novos instrumentos financeiros que é a governança corporativa torna a primeira parte do texto um pouco árida para leitores cujas preocupações estão distantes da arena financeira. As partes subseqüentes, creio que mais leves, pretendem mostrar como a governança corporativa vai se incorporando no discurso e na prática de alguns segmentos das velhas e novas elites brasileiras, quando então ganha inteligibilidade, passando a de ser considerada não uma fria ferramenta econômica, mas um artefato cultural dotado de muita plasticidade. Assim, a exemplo de outros instrumentos de ação empresarial e social, analisarei a difusão da governança corporativa no país como um caso de polissemia social (Donadone e
Grün, 2001). Esse segmento do texto culmina com o Quadro 1, no qual estão consolidados os interesses de cada grupo na evolução dessa governança corporativa, os avanços e a nuanças que cada uma das adesões produz na "nossa" governança corporativa. Para finalizar, exponho algumas conseqüências extraídas do caso brasileiro: primeiro sobre o funcionamento do capitalismo contemporâneo em geral e segundo sobre a dinâmica da importação e aclimatação de novidades econômicas e organizacionais.

\section{O que é governança corporativa}

"Governança corporativa" é uma expressão que vem se tornando conhecida em diversas áreas da sociedade brasileira, principalmente na atividade econômica; metaforicamente, em outras áreas. Ela engloba um conjunto de dispositivos, cada vez mais díspares quanto ao seu escopo e lógica interna, mas todos concorrendo para estabelecer ou manter uma relação entre acionistas e dirigentes das empresas, considerada satisfatória para os primeiros. Num nível alto de generalidade, os chamados "pilares da governança corporativa" são:

1. Respeito aos direitos dos acionistas minoritários.

2. Transparência nos procedimentos das empresas.

3. Possibilidade de aquisição do controle acionário das empresas através da compra de suas ações nos mercados financeiros.

Essas condições para a chamada "boa" governança corporativa ganham uma operacionalização específica no Brasil. Entre nós, o item 1 tem significado basicamente o direito de tag along: na eventualidade da venda do controle da empresa em questão, é a possibilidade de os minoritários venderem suas ações a preços equivalentes àqueles conseguidos pelos acionistas controladores; e a progressiva, ou definitiva, extinção das ações preferenciais: aquelas que não dão direito a voto nas assembléias de acionistas. ${ }^{1}$ 
O item 2 tem o sentido original de pregar por demonstrativos contábeis da situação e dos resultados das empresas, que não encubram dados fundamentais para a avaliação do seu desempenho e de seus dirigentes. Segundo a teoria da agência, que informa a visão positiva da governança corporativa, os acionistas e analistas financeiros, agentes exteriores à empresa, estariam numa posição de inferioridade estrutural relativa ao fluxo de informações relevantes sobre ela, e os demonstrativos contábeis deveriam ter por função primordial diminuir ou mesmo eliminar essa assimetria (Fama, 1980).

O item 3 diz respeito à expectativa de controle das atividades dos dirigentes das empresas (Fligstein e Friedland, 1995). Maior punição a atos seus considerados danosos para os acionistas seria a possibilidade de os descontentes entre eles se coligarem para substituir a direção atual da empresa. Para tanto é necessário que a quantidade de ações com direito a voto em poder do público externo seja maior do que aquela possuída pelos controladores originais, bem como a inexistência de cláusulas contratuais que impeçam o uso dessa opção. Esse item (3) é considerado o mais importante no modelo norte-americano, mas no Brasil parece não ter ganhado o mesmo status adquirido nos Estados Unidos, país de origem da idéia de "boa" governança corporativa.

Vê-se que a governança corporativa é um ideário típico do sistema financeiro norte-americano, mostrando-se como um instrumento na sua disputa secular contra as direções profissionais das empresas nas quais o capital captado e redistribuído pelos financistas é aplicado (Roe, 1994). Dessa maneira, o problema original que a governança corporativa procura resolver corresponde à configuração específica dos modelos anglo-saxões de capitalismo, nos quais o financiamento das empresas se faz pelo recurso aos aportes do público investidor em geral, em contraposição às outras situações, como as dos países da Europa Ocidental e Japão, nos quais a ligação do sistema bancário com as grandes empresas é mais estreita. Nestes casos, o problema original não existiria, já que os acionistas, reunidos em grandes blocos patrocinados pelos bancos, têm condições de fazer valer seus direitos e interesses direta e continuamente mediante de sua presença obrigatória nos comitês de administração (Roe, 1992).

Entretanto, o chamado big bang da internacionalização dos mercados financeiros dos anos de 1990 acabou generalizando as práticas norteamericanas, constituindo-se num dos aríetes mais potentes da "globalização" (Guillén, 2000; Streeck, 2001; Lane, 2003). É assim que assistimos nos últimos anos a difusão da governança corporativa em diversos países desenvolvidos ou em desenvolvimento. A militância dos atores nacionais que vêem na governança corporativa a salvação do capitalismo brasileiro é secundada por uma ação muito forte dos diversos organismos multinacionais, como a Organização para a Cooperação e Desenvolvimento Econômico (OCDE), o Banco Mundial e o Fundo Monetário Internacional (FMI), que divulgam as virtudes de práticas, a exemplo da governança corporativa, como condições necessárias à saúde econômica das sociedades que lançam mão de recursos daquelas entidades (Grün, 2003). Observando a sua cronologia, podemos ver que, em torno das virtudes atribuídas à governança corporativa, os setores das elites que a importaram dos Estados Unidos unemse a vários outros. É assim que, no seu nível mais alto de generalidade, a difusão da governança corporativa se faz pela cooptação de diversos setores das elites nacionais, demonstrando o papel de "cimento cognitivo" dos pré-julgados e as "ferramentas" oriundas do mundo financeiro internacional e o caráter de nova língua franca internacional assumido pela linguagem financeira (Boyer, 2002).

\section{A governança corporativa na história das "modas gerenciais" e nas disputas interprofissionais}

A prescrição sobre o funcionamento das relações entre os mercados financeiros e as empresas 
causa impacto também no funcionamento interno destas últimas. É assim que a governança corporativa brasileira também se inscreve na linhagem das chamadas "modas organizacionais" - a seqüência de instrumentos de atualização das formas de funcionamento das empresas que tiveram ou têm a qualidade suposta de revolucionar aquele espaço.

A partir daquele ramo genético podemos construir uma história da governança corporativa no Brasil, na qual a dinâmica de sua difusão tornase sociologicamente inteligível. Ainda que seja possível remontar a períodos mais antigos, podemos restituir a dinâmica de nosso objeto começando com os anos do pós-milagre. A crise econômica que se seguiu ao milagre econômico do início da década de 1970 parece ter criado um mercado para fórmulas de salvação da economia nacional. Nos anos de 1980 aparece a administração industrial japonesa com sua ênfase nas questões de qualidade. A solução ganhou ares messiânicos e sua mensagem ecoou para bem além da esfera da indústria de produção seriada para a qual ela foi originalmente criada. A qualidade não só salvaria a nossa indústria, mas também os diversos setores de serviços, incluindo cada vez mais esferas típicas da atuação governamental, como escolas e hospitais, e também a nossa agricultura. Em torno do sucesso da qualidade, muitos grupos de agentes valorizaram os seus trunfos profissionais e suas carreiras em geral. De início, abrangeu diversos tipos de consultores. Em seguida, tomou conta de setores das gerências das empresas, como o de recursos humanos e as diversas subáreas industriais, que eram pouco expressivos em períodos anteriores. Finalmente, atingiu os agentes do setor governamental, que começava a ser sacudido por uma maré intensa de deslegitimação. Como vemos, um verdadeiro bandwagon, fazendo muito barulho e assim amplificando interessadamente as virtudes e amplitudes da qualidade, num terreno tornado fértil pela súbita exposição das empresas brasileiras à concorrência internacional que ocorreu no governo Collor.

Reparemos que os economistas ficavam de fora daquela corrente. Ela unia os agentes especializados no que hoje estamos nos acostumando a chamar das condições microeconômicas para o desenvolvimento. A sinalização repercutia dentro das empresas, abrindo espaços para os setores profissionais eclipsados pelo predomínio dos financistas, como os engenheiros industriais e as profissões ligadas às relações de trabalho. Olhando pelo lado da disputa entre as profissões, tínhamos assim uma tensão sociológica empurrando a difusão da qualidade, que pode contribuir para explicar a impressionante velocidade da sua propagação nos mais diversos espaços de aplicação profissional.

No reverso, seria também sociologicamente provável que os economistas e financistas estivessem buscando alguma fórmula que os ajudasse a recuperar a primazia no mundo organizacional, diminuída no período anterior. Do ponto de vista da procura, estávamos assim diante de condições muito favoráveis para a acolhida e disseminação de idéias que valorizassem as suas habilidades ou pontos de vista no trato das questões internas às organizações. Do ponto de vista da oferta, a governança corporativa era um "produto" que atendia satisfatoriamente a essa demanda. Ela começa a tomar corpo no início dos anos de 1980 nos Estados Unidos, representando um novo estágio no predomínio da visão financeira na disputa interprofissional pelo controle das grandes corporações (Fligstein, 2001).A governança corporativa irá rezar que os aumentos de eficiência das organizações, das empresas em particular, seriam fruto da qualidade da vigilância (governança) que seus proprietários efetivos exerceriam sobre suas operações, e que essa qualidade é função de um ambiente institucional adequado para tal, salientado o papel de um mercado de capitais semelhante ao norte-americano e, mais genericamente, a um quadro legal respeitoso dos direitos de propriedade individual. Reparemos que, nesses termos, a governança corporativa também é adequada para instrumentar pretensões das profissões jurídicas para melhorar sua posição relativa no mundo econômico.

Não por acaso, as primeiras tentativas de difusão do novo instrumento no Brasil serão uma iniciativa conjunta de membros das duas profis- 
sões (Grün, 2003). E esses membros não seriam escolhidos ao acaso. Talvez não seja exagero dizer que a governança corporativa é uma espécie de coroamento do conjunto das principais soluções mágicas que advém dos conselhos dos órgãos financeiros internacionais para fomentar o desenvolvimento econômico - e, como veremos a seguir, também social - dos países menos desenvolvidos. Seus arautos serão indivíduos escolhidos entre os membros mais internacionalizados das profissões, chegando a rotular a governança corporativa como uma necessidade do mundo moderno e assim estigmatizando seus possíveis adversários como atrasados (Dezalay, 2002).

Nessa primeira etapa da difusão da governança corporativa, seu conteúdo estava inteiramente ligado à necessidade do estabelecimento de um quadro legal que aumentasse a confiança dos investidores no mercado de ações. De um lado, quanto à sua abrangência, tratava-se de uma discussão interna ao espaço dos negócios. Do outro lado, quanto à sua filiação em termos da nossa cultura econômica, podemos inscrever a idéia de governança corporativa na linhagem das posturas que enxergam que o nó do desenvolvimento brasileiro encontra-se na insegurança dos marcos jurídicos necessários para proteger e atrair os investidores. Nas discussões seculares, ${ }^{2}$ que culminaram com o debate sobre a industrialização dos anos de 1950, essa postura alardeava a necessidade de que o Brasil legal estivesse presente em toda a extensão do Brasil real. Ela era então uma posição defendida tipicamente por juristas e opunha-se ao desenvolvimentismo empalmado pelos engenheiros (Martins, 1976). Mais recentemente, a difusão do neo-institucionalismo econômico deu aos economistas uma plataforma teórica para engrossar esse coro (North, 1990).

No quadro montado por esses atores, os oponentes da governança corporativa eram uma nebulosa intitulada de "capitalismo tradicional brasileiro” (Agestado, 2000). Esse agrupamento compreendia desde os acionistas majoritários de empresas, que não queriam abrir mão de seus privilégios de controladores, até as parcelas do mercado de capitais e dos setores do governo e da imprensa, que não abraçavam a nova causa com a ênfase que seus arautos, achavam-na merecedora. Estávamos diante de uma típica disputa entre setores das elites tradicionais, na qual o grupo mais novo encontrava dificuldades para se instalar nas posições privilegiadas da sociedade e brandia a espada da contemporaneidade internacional para justificar a importância de seus trunfos.

A tramitação da nova versão da lei das sociedades no período FHC deu cores nítidas ao problema (Grün, 2003). Depois de intensa campanha de relações públicas em prol da aprovação de uma lei de "primeiro mundo", o Congresso nacional aprovou uma versão "cheia", considerada adequada pelos "modernos". Mas, quando o projeto foi encaminhado para a sanção na Presidência da República, então ocupada interinamente por Marco Maciel, ele o foi com vários vetos que diminuíram o alcance das novidades (Mattos, 2001).

\section{A governança corporativa na estratégia dos novos atores sociais}

A complexidade da questão aumentou quando entraram em campo novos atores, conformados segundo uma lógica aberta na redemocratização. O primeiro deles foram os fundos de pensão das empresas estatais. Embora existissem, em sua maioria, desde os anos de 1970, a sua importância relativa e independência na economia só ficaram patentes no início dos anos de 1990. Nesse momento, eles apareceram na cena econômica como atores incontornáveis, mas relativamente indóceis, para a estratégia de privatização e redesenho do Estado federal, empreendida pelo grupo em torno de Fernando Henrique Cardoso. Principalmente no primeiro período daquele governo, os dirigentes dos fundos de pensão foram pressionados a se alinharem ao figurino desenhado pelo grupo fernandista, para a venda das empresas estatais. Nele, lhes cabia a posição de "sociocapitalista" sem direito à partilha da gestão das empresas adquiridas. ${ }^{3}$ 
Colocar os fundos numa posição subordinada e mantê-los assim durante todo o período foi uma operação de deslegitimação executada a muitas mãos, e reveladora do funcionamento dos circuitos do poder na nossa sociedade atual. Durante todo o período, os fundos foram taxados de "corporativos" - e, portanto, atrasados - e, além disso, seus dirigentes foram postos na berlinda quanto à sua integridade. Essa operação simbólica teve a participação ativa da mídia, de diversos setores da academia, em especial entre os economistas e a participação mais diretamente interessada dos representantes de diversos bancos, em especial os de investimentos, para os quais a expectativa de acaparar os gigantescos recursos manejados pelos fundos era uma tentação inolvidável.

No auge do processo de deslegitimação, os fundos de pensão tentarão trazer para o Brasil uma justificativa para a sua existência baseada na idéia da "revolução das classes médias", da qual eles seriam os operadores. Essa idéia começa a ser propagada por Drucker (1976) e será empalmada pelos fundos de pensão norte-americanos por meio do que lá é chamado de shareboldism a militância dos acionistas em prol de seus direitos de propriedade, que estariam sendo esbulhados pelos administradores profissionais das corporações (Useem, 1993, 1996). É nesse quadro que a idéia de governança corporativa aparece como uma maneira privilegiada para os dirigentes dos fundos recuperarem uma imagem positiva e estabelecerem um quadro simbólico de confronto no qual eles poderiam ter capacidade de fogo. Eles irão abraçar a idéia da governança corporativa como uma causa mais abrangente, começando a configurar a situação em que vivemos mais recentemente. A diferença não estava propriamente no conteúdo intrínseco das medidas preconizadas, mas no enquadramento da questão. O primeiro grupo de difusores falava nos investidores em geral, implicitamente em indivíduos bem-sucedidos que aplicavam seus excedentes numa lógica interna das elites capitalistas. Os fundos de pensão brasileiros irão falar da governança corporativa como uma necessidade de proteger os pe- cúlios dos seus numerosos cotistas, "as famílias dos modestos funcionários das empresas estatais" (Waksman, 1997). Em março de 2004, esse grupo, considerado muito mais frágil e menos avisado do que os investidores individuais, era estimado em quase seis milhões de contribuintes, pensionistas e assistidos, (Abrapp, 2004).

Surge no cenário a versão brasileira das viúvas e órfãos que a legislação corporativa norteamericana pretende defender, pelo menos alusivamente. $^{4} \mathrm{E}$ a questão que antes interessava somente aos (poucos) participantes do mercado financeiro vai ganhar o estatuto de problema nacional, já que passa a ser de interesse direto de uma grande parcela da sociedade brasileira. Esse passo dificilmente poderia ser menosprezado, pois, não só no Brasil, mas internacionalmente, os mercados de capitais são estigmatizados como uma esfera de atuação econômica ilegítima, assemelhada a jogos de azar. Assim, os participantes dos mercados financeiros, ao aplicarem seus recursos em ativos "de risco", não mereceriam a nossa compaixão caso os perdessem. Segundo Raymundo Magliano, presidente da Bovespa, para que o nosso mercado de capitais se desenvolva: "O fundamental é a mudança cultural na imagem da Bovespa. A bolsa era vista como um cassino, era uma caixa-preta, uma casa de jogos. E, hoje, as pessoas falam em investir" (Pavini, 2004). ${ }^{5}$

A lógica social da nossa inovação financeira ganha ainda mais nuanças quando lembramos que, no período, os dirigentes tradicionais dos fundos de pensão também tiveram a sua legitimidade contestada por uma parcela grande de indivíduos egressos do movimento sindical ou do espaço político próximo. Nesse período de baixa atividade grevista (Noronha, no prelo), os fundos de pensão se tornaram alvos privilegiados para aqueles grupos manterem a sua atuação e importância na esfera pública. Vai daí que aparece uma tensão entre os diversos grupos de agentes que se digladiavam pelo controle dos fundos, na qual os egressos do movimento sindical apresentavam a representatividade alcançada em períodos anteriores da militância como seu maior trunfo. $\mathrm{Na}$ 
disputa simbólica que permeava o contencioso da representatividade, a governança corporativa aparece como uma questão anfíbia, não contida integralmente na esfera financeira, mas dotada de uma plasticidade que a remetia à esfera cívica. Afinal, o "direito de escolher os nossos dirigentes", a "transparência" e "direitos dos minoritários (das minorias)" são conceitos que iniciaram a sua carreira na esfera pública brasileira a partir da luta pela redemocratização dos anos de 1970 e 1980. Finalmente, "governança" entrou no nosso léxico mais recentemente, mas também "migrou" da esfera cívica para a financeira. Não é assim por acaso que os agentes vindos dos sindicatos, cujos trunfos iniciais originaram-se na prática política, irão abraçar a causa da governança corporativa e, eles também, contribuirão para ampliar o seu conteúdo e aumentar a sua legitimidade. ${ }^{6}$ Nos discursos dos grupos de sindicalistas atraídos pelos fundos de pensão, a aproximação entre acionistas minoritários e povo ganha mais verossimilhança.

\section{Governança corporativa: novidade financeira absorvida pelos atores políticos}

Esse movimento de migração da governança corporativa - da área financeira para a política - é uma tendência internacional, particularmente nos países da Europa Ocidental (Aglietta e Rebérioux, 2004). O ponto que nos singulariza é o cruzamento desse processo, que poderíamos chamar de "estrutural" do capitalismo moderno com a história e a cronologia específicas de nossa vida política. De início, a origem inequivocamente esquerdista das palavras fortes da governança corporativa no Brasil (transparência; direitos dos minoritários, direito de escolher os representantes); em seguida, a coincidência entre o momento decisivo do processo de difusão da governança corporativa no Brasil e a necessidade da candidatura Lula em fazer-se confiável diante dos mercados financeiros e de seus fazedores de opinião. Assistimos então o emblemático episódio da visita do então candidato à presidência da República à Bolsa de Valores de São Paulo (Bovespa) (Murphy, 2002; Ripardo, 2002). O ato, aparentemente inusitado, foi registrado e repercutido tanto pelo grupo do candidato como pelos visitados, denotando o interesse mútuo na aproximação. ${ }^{7}$ Pondo o evento em perspectiva, poderíamos colocá-lo como ponto culminante de uma cronologia que inicia com a disposição dos sindicalistas de disputar os cargos de direção dos fundos de pensão, sua participação nos episódios ligados à montagem dos consórcios que se lançaram na compra das estatais nos leilões de privatização e, mais amplamente, a participação sistemática dos sindicalistas na gestão dos grandes fundos sociais, como o FGTS (Fundo de Garantia por Tempo de Serviço) e o FAT (Fundo de Amparo ao Trabalhador). E as palavras de Lula naquele momento chancelam a legitimidade da governança corporativa: "É necessário proteger a sagrada poupança dos trabalhadores".

Lula na presidência da República irá seguir inicialmente o agora conhecido caminho-surpresa ortodoxo. Mas não sem sinalizar episodicamente a busca de alternativas, como o chamamento aos fundos de pensão internacionais, eles mesmos questionando seus engajamentos "ortodoxos" do passado (Walsh, 2002), a investirem seus capitais de longo prazo no Brasil (Batista, 2003), com resultados cada vez mais expressivos (Vieira, 2004).

Interessantemente, no início do governo Lula alguns contenciosos herdados do governo anterior irão testar, e provavelmente robustecer, a idéia da "boa" governança corporativa (Grün, 2004b). Os fundos de pensão se associaram a vários grupos de banqueiros e prestadores de serviços estrangeiros durante o processo de privatização e em outras empreitadas consideradas importantes pelo governo federal de então. Em muitas delas, a julgar pela reação posterior, a posição em que os fundos de pensão foram colocados foi considerada desvantajosa. Podemos mesmo dizer que a "moderna e globalizada" administração econômica do período FHC adotou uma curiosa atitude de prevenção e tutela em relação aos fundos de pensão, vigiandoos para induzi-los a utilizarem seus enormes capi- 
tais em empreitadas dirigidas pelos novos bancos de investimentos e impedindo-os de trilhar caminhos que conflitassem com esses últimos agentes. ${ }^{8}$

Uma vez Lula entronizado na Presidência da República, os fundos de pensão irão iniciar uma espécie de "reconquista", tentando recuperar-se das posições desvantajosas assumidas no período anterior. São emblemáticas as evoluções do controle da BrT - empresa de telefonia móvel operando no Oeste brasileiro e a desvalorização das ações preferenciais possuídas pela Previ na Ambev. O resultado pontual desses casos está "engessado" pelo quadro de constrangimentos herdados do governo passado.? Mas creio que o ponto mais importante a respeito deles seja o fato de que muito provavelmente deflagrarão ações governamentais na esfera da regulação legal e infralegal para aperfeiçoar a proteção aos acionistas minoritários e "preferencialistas".

O esforço retórico em prol da governança corporativa, empreendido no período FHC, mostrou seus limites nos episódios citados. É assim que os fundos de pensão foram uma espécie de zone de chasse gardé para alavancar o crescimento dos novos bancos de investimentos. Na hora de decidir as estratégias de investimentos no período passado eles eram claramente "patroneados" pelos representantes daquelas entidades financeiras sob a influência do pré-julgado então evidente que os verdadeiros "profissionais" do mercado financeiro seriam os jovens operadores dos novos bancos. Esse clima cultural, ao lado de pressões pontuais mais diretas, como a gestão de Solange Paiva na Secretaria de Previdência Complementar (SPC), ajudam-nos a entender as razões da aquiescência dos fundos de pensão para investimentos que posteriormente eles irão questionar com veemência (Agestado, 2000).

\section{A governança corporativa, os escândalos e os paradoxos do capitalismo atual}

$\mathrm{Na}$ esfera internacional, a fé na governança corporativa como princípio ordenador do capita- lismo contemporâneo foi abalado pelos escândalos da Enron, Worldcomm e de outras. A Enron, em especial, era uma das empresas até então consideradas "exemplares" das virtudes do atual modelo e seus dirigentes eram venerados na mesma intensidade. As diversas interpretações da sua débâcle constituem-se elas mesmas num interessante campo de estudos. Previsivelmente, alternamse as explicações que apontam a não-observância dos princípios "sadios" da governança corporativa e aqueles que contestam em bloco as virtudes gerais do modelo de gestão. ${ }^{10}$ De qualquer forma, um dos resultados da celeuma é a idéia de que a legislação norte-americana de então não era suficiente para atingir os objetivos que se esperava dela. A principal conseqüência foi a edição da Lei Sarbanes-Oxley, considerada um avanço em relação ao estado anterior da proteção legal que o acionista do mercado norte-americano tinha em relação ao comportamento dos responsáveis pelas empresas em que ele investiu (Blair, 2003a e b). E dada a centralidade do mercado financeiro norte-americano na economia mundial, os efeitos da nova legislação espraiam-se por todas as praças comerciais e industriais, já que ela pode questionar qualquer ato, mesmo no estrangeiro que possa produzir efeitos no valor das ações cotadas nos Estados Unidos (Gates, 2003).

Estamos diante de um paradoxo da regulação do capitalismo maduro. Os grandes líderes empresariais são incensados como a manifestação mesma do heró́smo econômico. Eles são remunerados como tal, "vendendo" a idéia de que a sua atuação é fundamental para valorizar os investimentos de seus acionistas. Uma das ações mais intensas nesse sentido são as séries seguidas de imprecações sobre como deve funcionar a economia, em especial exigindo o retraimento do Estado e da política em geral, estigmatizando essas esferas de atividade como irracionais. E uma das principais exigências nesse sentido é a de que o controle das atividades econômicas deve ser privilegiar a auto-regulação providenciada pelos pares em vez de promover intervenção em alguma agência estatal. Entretanto, os líderes empresariais dos últimos anos parecem corresponder 
mais ao figurino do "Faça o que eu digo, não faça o que eu faço". ${ }^{11}$ É assim que, diante das crises capitalistas recentes, aparece a boa e velha intervenção estatal, salvando os mercados do pânico generalizado, mesmo nos Estados Unidos E os dois casos mais dramáticos dos últimos anos mostram bem isso. No caso da crise gerada pela insolvência do fundo de investimentos LTCM, as autoridades financeiras restauram a liquidez financeira através de uma irrigação orquestrada pelo Federal Reserve Bank (FED) (Aglietta e Orléan, 2002; Mackenzie, 2003). Já no caso da crise deflagrada pela empresa de energia texana Enron, o legislativo federal restaurou a legitimidade dos mercados financeiros através da nova legislação que instaura a "verdadeira boa governança corporativa" (Blair, 2003a).

Outro ponto interessante a ser notado é que, diferente de outros momentos, no clima ideológico em que vivemos, as intervenções decisivas dos braços do Estado norte-americano não são registradas publicamente como a afirmação da necessidade do Estado como garantidor externo em última instância. Ao contrário, ao invés da fixação da idéia de uma entidade coletiva superior às vontades e capacidades de indivíduos "eleitos", fala-se mais na "clarividência de Greenspan", um "verdadeiro homem de mercado", ou nas virtudes dos diversos atores que negociaram a nova legislação.

Possivelmente, o clima de exaltação dos indivíduos excepcionais instaurado pela lógica da atividade de comunicação acaba desviando nossos olhos da lógica social das inovações financeiras (Manoff e Schudson, 1986; Huczynski, 1993). No caso presente da recuperação dos mercados após os escândalos corporativos, assim como em outros anteriores, o motor que rompe o business as usual é o clamor deflagrado por condutas consideradas imorais pelo público, que reage pressionando seus representantes no Legislativo e Executivo. E a necessidade de sobrevivência dos políticos acaba mobilizando-os para mais uma rodada de aperfeiçoamento institucional, que inicialmente é reprovada pelo business como uma intromissão indevida e prejudicial no seu espaço, para depois se transformar em uma plataforma virtuosa para novos ciclos de expansão capitalista. ${ }^{12}$

Vemos que a velha toada "é preciso salvar o capitalismo dos capitalistas" continua válida nos nossos tempos "pós-modernos". E os salva-vidas talvez tenham de ser recrutados em outras esferas de atividade que não o business, sob pena de estarem demasiadamente comprometidos com os interesses imediatos de algum grupo empresarial particular, em detrimento da estabilidade sistêmica. Não é assim por acaso que a tarefa de assegurá-la em condições de crise ou de preparar um nível mais elevado de atividade econômica é realizada normalmente por governos e indivíduos fora dos círculos internos e, mesmo conjunturalmente, em posição de antagonismo com os mercados. ${ }^{13}$ Assim, justifica-se esperarmos inovações institucionais importantes na esfera financeira em tempos de governos como o petista.

O exemplo brasileiro ajuda a esclarecer a questão. Numa atmosfera na qual a lógica dos argumentos e do envolvimento dos polemistas com eles pulsasse independente, poderíamos esperar que casos como a disputa Ambev versus Previ ou fundos de pensão versus Banco Opportunity transformar-se-iam em causes celèbres para os defensores dos princípios da governança corporativa nos "mercados", que poderíamos pensar serem os "intelectuais orgânicos" do neoliberalismo. Afinal, ainda que as ações dos grupos que nos dois casos disputam com os fundos de pensão pudessem ser consideradas legais no quadro jurídico em que foram estabelecidas, dificilmente elas poderiam ser consideradas "morais" num espaço cultural que confere à governança corporativa um valor positivo e fundamental para o desenvolvimento do capitalismo brasileiro. E, além disso, se considerarmos o número de associados dos fundos de pensão que tiveram seu patrimônio diminuído, bem como a magnitude dos valores em jogo, a importância das duas causas se agiganta. Entretanto, até agora não vimos nem Zola, nem j'accuse. ${ }^{14}$ Até onde a pesquisa na imprensa de negócios permite enxergar, os agentes que no período FHC defendiam veementemente a governança corporativa 
mantém-se muito pouco expressivos diante dos dois casos. E assim, são os próprios dirigentes dos fundos de pensão e seus aliados no governo que se tornam os defensores diretos da causa da governança corporativa no Brasil.

\section{Um encontro inesperado: a governança corporativa e a "responsabilidade social" das empresas}

Porém, com ou sem percalços, eis que nossa parada continua. O bandwagon da governança corporativa passa pelo conjunto da sociedade e conquista novos seguidores. Ecoando uma tendência internacional, que se intensificou no mundo corporativo depois da débâcle da Enron, a governança corporativa brasileira irá, ela também, agregar a necessidade da "responsabilidade social" das empresas.

Inicialmente, a responsabilidade social das empresas é um conjunto de iniciativas justificadas nelas mesmas e estritamente voluntárias. Mais recentemente, a "responsabilidade social" tornou-se ao mesmo tempo muito mais visível do que no período anterior e foi incorporada ao esqueleto da governança corporativa praticamente como uma obrigação das empresas (Carvalho, 2004a; 2004b).

Diante do susto recente, a primeira justificativa para a incorporação do novo "módulo" de obrigações da empresa é a necessidade de se prevenir "riscos morais" que poderiam afetar drasticamente o seu valor (Vieira, 2004). Esses riscos seriam advindos de comportamentos moralmente questionáveis dos membros da empresa que redundariam no enriquecimento privado deles em detrimento do da empresa e de seus acionistas. Um caso típico é a produção ou conivência com manipulações contábeis que inflam artificialmente os lucros, gerando maior valor para as stock-options, recebidas prioritariamente pelos dirigentes das empresas, mas cada vez mais difundidas como forma de remuneração variável e motivadora para os seus escalões intermediários. A lógica subjacente ao estímulo às ações de responsabilidade social é que empregados e dirigentes das empresas devem ser dotados de boa moral e as ações beneméritas ao mesmo tempo comprovam e aprofundam esse traço nas personalidades dos integrantes das corporações, diminuindo o risco de ações questionáveis como no exemplo acima.

A questão tem evoluído rapidamente, mostrando que havia virtude represada no mundo empresarial e que, enfim, ela encontrou uma linguagem e uma justificativa para apresentar-se. Novos temas e preocupações têm sido constantemente agregados ao rol de itens que merecem a atenção e a intervenção benfazeja dos indivíduos e organizações que agem em nome das empresas. Assim, preocupações com o trabalho infantil somam-se a cuidados com a qualidade da educação fundamental, com a saúde reprodutiva e quaisquer outras causas que sensibilizam os indivíduos e grupos.

O entusiasmo gerado pelas atividades de benemerência é enquadrado, mediado e em grande parte sugerido, por esse novo gênero de empreendedor moral, cada vez mais profissionalizado e distinto, tanto das antigas formas de filantropia como da ação social tradicional das agências de Estado. Nesse sentido, é difícil deixar de notar a presença do selo "Balanço Social Ibase/Betinho" nos balanços sociais de uma quantidade crescente de grandes empresas. Por outro lado, aparece também a contribuição de organizações como o Instituto Ethos propondo ações sociais e preparando membros das empresas nessa atividade. E olhando para as atividades passadas das duas entidades e de seus colaboradores, é difícil não notar a legitimidade construída no passado, primeiro em torno da figura quase mítica de Betinho e em seguida de realizações importantes como as campanhas contra as insuficiências alimentares da população carente brasileira e a luta contra o trabalho infantil. ${ }^{15}$

Dada essa expressiva quantidade de agentes ligados a campanhas cívicas e eventos antiglobalização nesse novo segmento de atividade, parece que estamos assistindo a enfim realizada aproximação efetiva da elite empresarial representada 
pelo Fórum dos "líderes mundiais" de Davos com vários setores dentre os organizadores do Fórum Social de Porto Alegre (Rossi, 2003). Personagens como Oded Grajew são típicos dessa "dupla militância”. Eis que, no site do Banco Mundial, aparecem alguns pontos da sua biografia: ${ }^{16}$ Engenheiro elétrico formado na Escola Politécnica da USP e pós-graduado em Administração de Empresas na FGV; em 1972, fundou a Grow - jogos e brinquedos; em 1989, foi um dos fundadores do PNBE Pensamento Nacional das Bases Empresariais; em 1990, fundador da Abrinq - Associação Brasileira dos Fabricantes de Brinquedos, responsável por projetos sociais tendo por alvo questões da infância, em especial a luta contra o trabalho infantil, utilizando o conceito de cadeia produtiva para estender o alcance do movimento; 1998, fundador do Instituto Ethos, para difundir a idéia de responsabilidade social no meio empresarial e, curiosamente sem data nem alcance definido, "fundador e dirigente do Fórum Social Mundial (Fórum de Porto Alegre)". ${ }^{17}$ Além disso, cumpre notar seu papel de assessor do Presidente Lula durante seus primeiros meses de governo (Valor Econômico, 2003; Mignone, 2003).

A incorporação desse segmento da sociedade, normalmente contestador, pode ser considerado uma variante do que Boltanski e Chiapello (1999) chamaram de "recuperação da crítica artista na época do terceiro espírito do capitalismo". A chamada "crítica artista" é aquela que aponta a "falta de alma" do sistema, a sua insensibilidade para temas que interferem na vida dos indivíduos, mas não nos lucros das empresas. A neutralização desse gênero de ataque, que vêm se mostrando, nos últimos anos, mais corrosivo do que a tradicional contestação operária, aponta uma característica das mais interessantes da governança corporativa brasileira e da complexidade do capitalismo contemporâneo em geral. ${ }^{18} \mathrm{O}$ nosso espírito de Porto Alegre é internacionalmente chamado de "alter-mundialismo" e é lembrado como uma das contestações mais agudas e importantes à "globalização capitalista". ${ }^{19}$ Logo, seus promotores são talvez os contestadores da ordem capita- lista atualmente mais legitimados, tanto nacional como internacionalmente. Quando esses atores, investidos da mais alta autoridade moral, dizem que as empresas capitalistas foram até agora negligentes nas suas funções sociais, mas que ultimamente elas encontraram o caminho da recuperação do tempo e das oportunidades perdidas, eles têm todas as chances de ser acatados.

Ainda mais recentemente, surge a idéia de "sustentabilidade" das empresas. Em construção no momento, essa idéia que faz parte do conjunto de preocupações da responsabilidade social empresarial, um novo módulo referente aos impactos que os produtos fabricados ou comercializados pelas empresas geram na sociedade ou no meio ambiente. ${ }^{20}$ Além dos problemas sociais e ecológicos considerados intrinsecamente, o novo desdobramento se justifica na lógica de que uma empresa que comercializa produtos potencialmente perigosos poderá ter seu futuro em jogo quando (e se) a sociedade tornar-se consciente dos perigos. ${ }^{21}$ Isso porque a consciência terminaria por inviabilizar a empresa, seja legalmente, seja afastando seus clientes, e pulverizar, ou simplesmente diminuir, o valor de suas ações no mercado. Assim, o "índice de sustentabilidade" deve funcionar como uma métrica que antecipa esses riscos, e os "precifica". Dessa forma, estão se criando critérios para ponderar, por exemplo, a ação social produzida por uma empresa fabricante de cigarros, produto potencialmente nocivo à saúde dos consumidores e à saúde pública em geral, ou, analogamente, critérios para avaliar os benefícios e danos causados por uma empresa de celulose empenhada em ações de responsabilidade social, mas cujo parque florestal possa causar danos à biodiversidade.

\section{A governança corporativa mudando a tradição brasileira}

Num outro canto da nossa ágora, o eco da governança corporativa brasileira espraia sua linguagem, e talvez o seu espírito, num espaço pou- 
co esperado, enquadrando as remodelações organizacionais de grupos empresariais familiares. Grupos como a Companhia Brasileira de Distribuição (Grupo Pão de Açúcar) e Votorantin organizam a sucessão geracional e reorganizações de menor alcance a partir das idéias que a governança corporativa pôs na agenda (Anaya, 2002; Valor Econômico, 2001, 2002).

Aí aparece outro paralelo interessante. Nos anos de 1960 e 1970, a idéia de departamentalização cumpria papel semelhante, fornecendo vocabulário, justificativa e uma blue print suficientemente flexível para enquadrar processos, mutatis mutandis, análogos. Naqueles tempos mais tecnocráticos, a delimitação das autoridades e responsabilidades que a departamentalização sugeria tinha por corolário a "profissionalização" da direção das empresas familiares (Koontz, 1962; Motta, 1968). De um lado, problemas diagnosticados, como a falta e a necessidade de profissionalização das direções dos grupos e de suas empresas componentes, recebiam uma justificativa para a transição que significava a entrega da administração direta dos empreendimentos a gerentes profissionais. Esse resultado foi alcançado no seu tempo pela "departamentalização" (Motta, 1968). Mas nosso bandwagon atual vai mais longe. Ele sugere e confere legitimidade à criação de novas instâncias deliberativas que realizam a transição entre a ordem doméstica das relações pessoais e familiares entre os sócios das empresas e a ordem comercial e financeira típica e legítima da vida corporativa. ${ }^{22}$

A adesão de parcela expressiva do empresariado tradicional ao léxico da governança corporativa é curiosa. Afinal, o espírito original da governança corporativa é uma contraposição direta às práticas societárias e sucessórias que nossas dinastias empresariais se acostumaram ao longo dos anos. Esse espírito "pré-napoleônico" outorga o negócio para o herdeiro eleito, representado pela administração dos empreendimentos de propriedade da família, e o ócio, representado por rendas de diversa natureza, como os rendimentos de ações preferenciais e de aluguéis, para os preteridos. Mas será que esse arranjo tradicional já não está ele mesmo deslegitimado culturalmente, faltando apenas um novo léxico para legitimar o seu abandono? E, nesse caso, não seria a passagem do bandwagon da governança corporativa uma coincidência adequada para facilitar a mudança, que, no limite, confere aos proprietários absenteístas mais poderes, mas também maiores responsabilidades, descaracterizando a expressão mesma de "absenteísta"?

A linguagem da governança corporativa tem características anfíbias que a predispõe a servir a esse propósito. De um lado, a sua origem no mundo cívico; do outro, o seu desenvolvimento na esfera econômica: a junção dessas duas características tornam-na adequada para expressar e regular os incômodos no seio das dinastias empresariais. A irrupção do movimento feminista na esfera pública, principalmente na sua dimensão cívica, transformou as sensibilidades da esfera doméstica, tornando ilegítimas as formas anteriores de sucessão familiar. ${ }^{23}$ Entretanto, os incômodos dos preteridos (fundamentalmente as preteridas) não tinham linguagem para se expressar legitimamente na esfera legal-comercial. A governança corporativa fornece essa linguagem, viabilizando as transformações.

Aparecem então na cena empresarial os $f a$ mily offices e os "conselhos de família" (Kênia, 2002), os novos braços da governança corporativa - a recém-chamada "governança familiar", devidamente organizada como pacote de treinamento e de consultoria. ${ }^{24} \mathrm{~A}$ inovação fica clara tanto no lado da demanda como da oferta. Nas propostas anteriores, como a da departamentalização, a questão fundamental era a da profissionalização dos herdeiros das famílias proprietárias. Agora, temos um ferramental para pensar e operacionalizar a relação entre as famílias e as diretorias profissionais, bem como para que os membros das famílias sem participação direta nos negócios possam monitorar as atividades daqueles que ali têm responsabilidade direta. Do lado da oferta, o ímpeto para a sua difusão explica-se pelo fato de que o conjunto de ferramentas organizacionais constituise num fundo de comércio para vários arautos da 


\section{Quadro 1}

\section{Extensão dos Atores e dos Sentidos da Governança Corporativa no Brasil}

\begin{tabular}{|c|c|c|c|c|}
\hline Atores & Alcance & Influência & Interesse específico & Ampliação de sentido \\
\hline Chicago Boys & Grandes investidores & $\begin{array}{l}\text { Mercado, mídia, par- } \\
\text { lamento, academia, } \\
\text { fundos }\end{array}$ & Aumentar mercado & Originadores \\
\hline $\begin{array}{l}\text { Gestores dos fundos } \\
\text { de pensão }\end{array}$ & Cotistas dos fundos & $\begin{array}{l}\text { Funcionários das es- } \\
\text { tatais, sindicalistas }\end{array}$ & $\begin{array}{l}\text { Legitimidade; segu- } \\
\text { rança; investimentos }\end{array}$ & $\begin{array}{l}\text { Problema social: pro- } \\
\text { teger velhinhos, viú- } \\
\text { vas e órfãos (os "pou- } \\
\text { cos milhões" de } \\
\text { cotistas) }\end{array}$ \\
\hline $\begin{array}{l}\text { Sindicalistas e esquer- } \\
\text { da sindical }\end{array}$ & Trabalhadores & $\begin{array}{l}\text { Público sensível à } \\
\text { pregação esquerdista } \\
\text { e sindical }\end{array}$ & $\begin{array}{l}\text { Ocupar espaços de } \\
\text { representação }\end{array}$ & $\begin{array}{l}\text { Problema social mais } \\
\text { amplo: proteção dos } \\
\text { sindicalizados }\end{array}$ \\
\hline Governo Lula & Trabalhadores & Sociedade em geral & $\begin{array}{l}\text { Legitimidade diante } \\
\text { dos mercados }\end{array}$ & $\begin{array}{l}\text { Problema social ainda } \\
\text { mais amplo: proteção } \\
\text { dos trabalhadores }\end{array}$ \\
\hline $\begin{array}{l}\text { Esquerda "basista" ou } \\
\text { "artista" }\end{array}$ & Nação & $\begin{array}{l}\text { Setores "antiinstitucio- } \\
\text { nais", empresas e seus } \\
\text { funcionários da ativa }\end{array}$ & $\begin{array}{l}\text { Disseminar boas práti- } \\
\text { cas; fundo de comér- } \\
\text { cio }\end{array}$ & $\begin{array}{l}\text { Equivalência entre } \\
\text { boas práticas empre- } \\
\text { sariais e boas práticas } \\
\text { sociais }\end{array}$ \\
\hline $\begin{array}{l}\text { Consultores Organi- } \\
\text { zacionais }\end{array}$ & $\begin{array}{l}\text { Empresários tradicio- } \\
\text { nais }\end{array}$ & $\begin{array}{l}\text { Empresários tradicio- } \\
\text { nais; parte dos políti- } \\
\text { cos }\end{array}$ & $\begin{array}{l}\text { Novos fundos de co- } \\
\text { mércio: o "negócio" } \\
\text { da sucessão empresa- } \\
\text { rial é jurídico ou or- } \\
\text { ganizacional? }\end{array}$ & 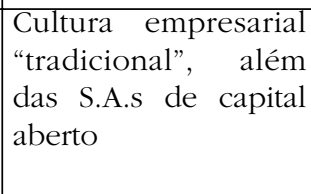 \\
\hline
\end{tabular}

governança corporativa, que os propagam e consagram-se como seus operadores legítimos. Nesse processo podemos assim verificar o caráter não só prático, como também legitimatório, dos novos instrumentos e de seus operadores.

Uma esquematização das tramas entrelaçadas leva-nos ao Quadro 1. Notemos que a polissemia produz-se principalmente quando cada novo grupo que passa a acompanhar o bandwagon incorpora suas preocupações à panóplia da governança corporativa e, assim, por uma mudança de ênfase, acaba alterando o centro de gravidade das discussões sobre a governança corporativa e seu significado social (Goodman, 1978; Bourdieu, 1997).

\section{Conclusão}

A governança corporativa era uma espécie estranha em terras brasileiras. Tudo indica que nos últimos anos deixou de sê-lo. A análise da sua aclimatação permite-nos algumas conclusões sobre a importação, criação e difusão de mudanças organizacionais e de novas institucionalidades em geral. A primeira reação dos analistas diante dessas novidades costuma-se dividir polarmente. De um lado, há os "negacionistas": uma vez que organizações e instituições são estruturas sociais, essa posição costuma desdenhar da possibilidade de elas serem transplantadas de um corpo social para outro. ${ }^{25}$ No pólo oposto, construiu-se o entendimento que a novidade em questão representa o supra-sumo do mundo moderno e que devemos fazer de tudo para nos adaptarmos a ela. Aî se encontram os nossos já conhecidos zelotes do neoliberalismo, exigindo que nos transformemos em filiais reais dos seus modelos virtuais. Constatamos que essa árvore estranha prospera em terras brasileiras. Mas será que ela continua tão estranha assim? Da nossa análise depreende-se que não só ela se acostumou conosco, como, principalmente, nós nos acostumamos a ela, mas, ao 
acolhê-la, nós lhe imprimimos a nossa marca, como está mostrado no Quadro 1.

A nossa governança corporativa é aquela dos modelos? Parece que não. Para aclimatar-se no Brasil, ela sofreu uma "engenharia social genética" que a transformou numa variedade nativa, capaz de propagar-se naturalmente no novo solo. A exemplo de outras inovações organizacionais e institucionais, e para desespero dos adeptos da globalização passiva, a "nossa" governança corporativa foi mais uma reinvenção da roda (Cole, 1989). O preço da sua difusão teria sido a sua "conspurcação", através do seu uso e de sua transformação nas estratégias de diversos grupos de atores nacionais. Obviamente que a extensão diminui o fundo de comércio potencial, tanto o literal como o simbólico dos seus introdutores, que perdem o seu rendimento total, tendo de se contentar em administrar o goodwill. Mas na trama social que descrevemos, a extensão de sentidos e de práticas associadas à governança corporativa parece ser uma condição necessária para a sua difusão.

Será que poderíamos separar a lógica da adoção da lógica do funcionamento "em regime" da nossa novidade institucional? Se o corte for adequado, a primeira seria particular a cada país, mas a segunda apresentaria um modus operandi internacional, cumprindo o vaticínio dos prosélitos da globalização. Neste caso, nossa peculiaridade seria apenas na esfera da difusão. Obviamente não temos elementos para afirmar definitivamente o acerto de nenhuma das duas possibilidades, mas as tramas entrelaçadas nos dizem que a balança pende para a ênfase nas particularidades.

Será que as difusões de ondas organizacionais e econômicas do passado nos ajudam a entender a atual? A última onda, a da Qualidade, foi claramente "coletivista". Ainda que podendo ter um viés anti-sindical, ela valorizava a "comunidade de produtores", anunciando a união de todos pelo aumento da qualidade e produtividade. Em mais uma manifestação da lógica pendular que rege a difusão de novidades organizacionais (Eccles et al., 1992), a resposta não tardou: começou pela panóplia Re-engenharia \& Downsizing \&
Produção enxuta, passou pelo custeio ABC (Armstrong, 2002), pelos sistemas informáticos integrados do gênero ERP (Koch, 2001), pelos BSCs (Norreklit, 2000) e chegando até os EVAs (Lordon, 2000b). E finalmente, todo esse esforço individualizante culmina na governança corporativa.

Mas eis que diante dos escândalos da Enron e análogos, a governança corporativa tem mostrado sua enorme vitalidade. Quando o pêndulo chegou ao seu extremo individualizante e se desgastou, ela se corrigiu, incorporando a idéia de responsabilidade social e reintroduziu idéias da família argumentativa hierárquica/coletivista (Douglas, 1996), sendo assim capaz de absorver a onda contrária. Mais do que isso, se na matriz norte-americana a filantropia sempre foi um assunto tipicamente privado, no qual o Estado sempre foi um ator contestado, entre nós, a questão vem ganhando outros contornos. Se houve tempo em que os empresários podiam dizer que seu papel na sociedade era simplesmente ganhar dinheiro para gerar empregos e impostos, o avanço da responsabilidade social alterou a idéia da função legítima desse ator. Assim, de um lado temos empresários com mais responsabilidades, mas do outro temos um acréscimo importante na legitimidade do mundo dos negócios na sociedade.

No plano mais geral, podemos identificar novas cumplicidades entre esses grupos de atores que conquistaram, a diversos títulos e a partir de posições diferentes, o direito de ser ouvidos sobre os destinos da nação e assim fazerem parte do circuito do poder na nossa sociedade cada vez mais complexa. No decorrer de nossa história, os diferentes "cacifes" predispunham os agentes a entrarem prioritariamente em disputa pela afirmação de qual deles era mais importante e pelas taxas de câmbio entre as diversas notoriedades em geral. O poder sindical era antagônico ao poder empresarial; os fundos de pensão tinham relações tensas com os investidores tradicionais dos mercados financeiros e assim por diante. Uma das forças de dispositivos como a nossa governança corporativa é de congregar esses diversos grupos, atribuindo a cada um deles uma fatia dessa torta genero- 
sa que é o controle da riqueza nacional e um quadro de referências comum para tratar eventuais contenciosos. Assim, a análise da governança corporativa mostra-nos que o mundo das finanças, mais ou menos docemente, é capaz de obrigar outros setores das elites nacionais a se expressarem na sua língua.

Mas resta saber quem fica de fora dessa redistribuição material e simbólica. A adesão à governança corporativa dos setores que representam a esquerda e os trabalhadores da ativa deu-se num período marcado por particularidades que talvez não se mantenham. O clima de "salve-se quem puder" no mercado de trabalho tornou os trabalhadores pouco propensos a apostar suas fichas na contestação sindical, tanto contra patrões, quanto contra as direções sindicais estabelecidas.

A experiência internacional sobre a relação entre assalariados e a governança corporativa é muito pouco conclusiva. À primeira vista, parece lógico que aqueles que extraem o essencial dos rendimentos de seu trabalho sintam-se inseguros num regime de gestão empresarial no qual os interesses dos acionistas sejam invocados todo o tempo (Lordon, 2000a). Afinal, fala-se muito que os acionistas se interessam sobretudo pela maximização dos lucros das empresas no curto prazo e isso costuma significar menor segurança no emprego e menores gastos das empresas com o bem-estar e o avanço profissional de seus funcionários. De maneira geral, há o temor que a introdução da governança corporativa em países de outras tradições de relações industriais levaria ao esgarçamento de práticas harmônicas que unem os trabalhadores às direções das empresas, com reflexos negativos sobre a cooperação entre esses atores, considerada peça-chave para explicar os sucessos industriais alemão, escandinavo e japonês (Guillén, 2000).

Entretanto, talvez estejamos subestimando os efeitos práticos da teoria (Hacking, 2003; 2004). A inscrição da governança corporativa na história das ferramentas organizacionais inseriu-a no ápice de um processo de individualização progressiva da medida do desempenho dos empre- gados das empresas. Esse crescendo torna cada vez mais real a idéia, antes absurda, de que as empresas são arranjos contingentes de atores que participam de um mesmo projeto hoje e que posteriormente se distanciarão em suas novas empreitadas (Boltanski e Chiapello, 1999; Powell, 2001). Aplicadas sistematicamente nos espaços organizacionais não-anglo-saxões, as ferramentas parecem já ter esgarçado os tecidos sociais das empresas, provavelmente sem que os analistas que duvidavam da pertinência da governança corporativa se dessem conta. ${ }^{26}$

Por outro lado, apontamos a possível inflexão cognitiva associada à idéia de responsabilidade social. Creio que essa idéia é particularmente forte no Brasil. Numa primeira reação podemos achar que estamos diante de meras operações de relações públicas, condenadas a um rápido esquecimento. Mas parece que a lógica social empurra-nos para um desfecho diferente. Assim, dadas as conhecidas carências do nosso cordão de segurança social e a imagem negativa que os governos ganharam como possíveis solucionadores desse problema, a entrada sistemática das empresas no setor tende a ser muito bem recebida e estimulada, obrigando os atores a manter e mesmo aprofundar seus engajamentos e, talvez, fazendoos introjetar a responsabilidade social como uma regra cívica durável. ${ }^{27}$ Mas haveria mesmo a correlação entre o engajamento das empresas nas atividades benemerentes e a redução do "risco moral"? Além dessa finalidade imediata, haveria mesmo uma relação positiva entre os engajamentos sociais das empresas e a diminuição do individualismo no seio das empresas?

Temos no momento um excelente instrumento para avaliar a intensidade e os meandros da aproximação entre nossos empreendedores morais e os empresários engajados nas ações de responsabilidade social. Está aberto um contencioso sobre como se avaliar a responsabilidade social de empresas de tabaco e outras cujos produtos são questionáveis. De maneira geral, segundo a norma desejada pelas empresas interessadas, os possíveis problemas causados por seus produtos ou proces- 
sos de fabricação devem ser "precificados", afetando negativamente o chamado "índice de sustentabilidade" da empresa, podendo assim ser compensados por um acréscimo de atividades benfazejas distantes da atividade central da empresa. Mas essa quantificação incomoda vivamente as sensibilidades sociais e ecológicas de representantes dos institutos que propõem as atividades da responsabilidade social e seus certificadores (Camba, 2005). Ao que parece, para estes últimos, produtos e processos que causam danos à sociedade ou ao meio ambiente deveriam simplesmente ser descontinuados e assim as empresas que os fabricam deveriam estar de fora da notação do "índice de sustentabilidade". Entretanto, a "precificação" pode ser considerada a essência mesma da maneira "neoliberal" de dar conta dos problemas causados pelas empresas. Nesse ponto, os habitus originais se chocam e a evolução da composição entre as partes mostrará os mecanismos e os limites da aproximação entre atores conformados, originalmente, segundo lógicas bem diferentes.

A idéia de "campo do poder" (Bourdieu, 1989) nos ajuda a pensar com mais segurança o futuro da configuração que esbocei. Se de um lado a extensão da governança corporativa mostrou a aceitação das elites sindicais e políticas de esquerda, bem como das dinastias empresariais, aos pré-julgados financeiros, do outro lado, a sensibilidade e as exigências sociais destes dois últimos grupos também "contaminaram" os atores empresariais. E a extensão dos circuitos de legitimação joga no sentido de estabilizar os comportamentos de cada grupo pela vigilância recíproca e pelo interesse em ser aceito pelos demais elos da cadeia. Os empresários ganham legitimidade social. Os sindicalistas ganham legitimidade econômica. Os empreendedores sociais conseguem conferir cidadania econômica e social para suas atividades profissionais e separá-las cognitivamente da filantropia tradicional. Mas cada um dos grupos é fiador da sinceridade da conversão e dos propósitos dos outros. Por sua vez, os membros não diretamente ativos das dinastias econômicas conseguem conferir legitimidade ao seu compor- tamento e reclamos, ganhando cidadania no mundo moderno. Mas somente depois de coonestar os princípios gerais da governança corporativa. Dessa maneira, diminuem reciprocamente os graus de liberdade, tanto discursiva como prática, dos quatro grupos. Mas a estabilidade simbólica do capitalismo brasileiro, que em última instância é o mais forte indicador da sua estabilidade sistêmica, esta aumenta exponencialmente. Assim, podemos inferir que estaremos menos sujeitos a grandes abalos, mas também teremos menos esperanças de mudanças drásticas que possam trazer novidades significativas na nossa paisagem social.

\section{NOTAS}

1 Esse problema recebeu grande publicidade a partir do contencioso aberto entre a Previ (Fundo de Pensão dos Funcionários o Banco do Brasil) e os então controladores da Companhia de Bebidas das Américas (Ambev) quando da fusão ou incorporação da empresa pela Interbrew belga. A Previ possuía $12 \%$ das ações preferenciais da companhia original e esse patrimônio expressivo foi duramente desvalorizado depois da criação da nova empresa.

2 Nesse sentido, podemos achar um esboço dessa posição já nos mascates do Pernambuco colonial, no seu confronto com a aristocracia açucareira (Mello, 1995).

3 Essa questão tornou-se pública pelas tentativas de rearranjos societários pós-privatização que estão ocorrendo no governo Lula, dos quais os episódios envolvendo a Kroll são a face mais ruidosa (Michael, 2004). Nelas, os fundos de pensão tentam reverter acordos anteriores como o da BrT e da Telemar. Com isso, deflagrou-se, ou atualizou-se, um contencioso que rapidamente atingiu a cena política e tornou-se um divisor de águas bem claro entre a estrutura do sistema financeiro desejado pelo grupo tucano e aquele que os petistas parecem abraçar (Grün, 2004a).

4 Sobre a história da governança corporativa norteamericana, ver Roe (1994). 
5 Uma "arqueologia" do tratamento sociológico do problema da indisposição social em relação aos mercados financeiros sendo atiçada pelos populismos começa em Marx e Engels (1950), passando por Weber (1987 [1898]) e Schumpeter (1991). Os trabalhos de Sternhell (1991; 1994) e Birnbaum (1979) contextualizam a questão da plutocracia na história européia da virada do século XIX com o $\mathrm{XX}$, mostrando diretamente como o então nascente fascismo europeu nutria-se daquele clima cultural e, indiretamente, as dificuldades de uma possível postura antiplutocrata que não se deixasse contaminar pelos temas e clima que geraram o fascismo e o anti-semitismo europeus. Mackenzie e Millo (2003) mostram alguns passos concretos do trabalho de legitimação necessário para viabilizar o moderno mercado norte-americano de opções, proibido durante muitos anos depois da grande depressão, realizado por agentes ligados ao mercado financeiro e da academia daquele país.

6 É difícil não reconhecer o paradoxo: na segunda metade do século XIX, Marx alertava para a paródia de democracia que então se esboçava através das assembléias de acionistas das primeiras sociedades anônimas. No final do século XX, os sindicalistas contribuem decisivamente para conferir verossimilhança à metáfora.

7 Devemos lembrar o contexto do momento. Diante da expectativa da vitória de Lula, começaram os rumores da possível "argentinização" do Brasil - uma vez Lula eleito, haveria uma corrida contra o real que tornaria o país ingovernável, precipitando a sua renúncia e mesmo um possível retrocesso antidemocrático, a exemplo do que se interpretava naquele momento sobre Fernando de la Rua em relação à presidência da Argentina. Essa versão interessava aos concorrentes de Lula, em especial ao candidato do PSDB, que se assim colocava como garantidor de estabilidade econômica. Evidentemente, os mercados financeiros começaram a especular a possibilidade de crise generalizada, "precificando-a", precipitando uma corrida contra o real e lucrando contra as contas nacionais, já que as autoridades monetárias tinham de tentar dimi- nuir a especulação comprando reais e vendendo dólares a preços desvantajosos para o erário. Talvez um dia saibamos se as garantias que Lula ofereceu aos mercados financeiros - a mais eloqüente foi a "Carta aos Brasileiros" - foram eficientes como uma maneira de evitar uma crise ainda maior.

8 Lembremos que o fortalecimento dos fundos de pensão é um dos pontos mais fortes das estratégias de modernização neoliberais preconizadas pelos organismos econômicos internacionais. No Brasil do período FHC parece ter prevalecido a idéia de que os fundos de pensão eram uma simples extensão do execrado corporativismo atribuído aos funcionários das empresas estatais, ainda que os grandes e mais conhecidos fundos norte-americanos também sejam patrocinados por órgãos governamentais e nem por isso percam legitimidade diante dos agentes financeiros "sérios" (Grün, 2003).

9 Um ponto de divisão interessante é o papel que a Comissão de Valores Mobiliários (CVM) deve assumir na estrutura legal da governança corporativa brasileira. O episódio da disputa entre a direção da Ambev e a Previ sobre o tag along das ações preferenciais da companhia, detidas pelo fundo de pensão, é ilustrativo. Mesmo em 2004, diretores da CVM, indicados no governo anterior, mantêm claramente a linha de que ela deve proteger exclusivamente os pequenos investidores contra golpes que investidores "profissionais" deveriam estar preparados para evitar sozinhos. É assim que eles justificam não dar provimento às reclamações da Previ contra a incorporação da Ambev à cervejaria belga Interbrew. As palavras do então presidente da CVM, Luiz Leonardo Cantidiano são ilustrativas (nomeado no período FHC, então já com o substituto anunciado): "A CVM tem a obrigação de zelar pelo pequeno e médio investidor. $O$ investidor grande sabe se proteger. Se escolheu um mau sócio, o problema é dele" (Balarin, 2004). É interessante a identidade presumida: grande $=$ avisado. As possíveis ingerências nas decisões tomadas pelos fundos de pensão, realizadas por atores externos movidos por pautas heteronômicas, não são aí vis- 
tas como constrangimentos que mereçam ser impedidos ou corrigidos. E quem imagina que o governo Lula poderia trazer diferenças diretas na questão talvez se sinta decepcionado: a postura pública de Marcelo Trindade, o presidente da CVM indicado por Lula, a respeito da questão não parece ser diferente daquela de seu antecessor, talvez mostrando a força e autonomia dos mercados financeiros diante dos governos (Barros, 10/4/2004). Aos meus olhos, a análise dos subentendidos desse "estilo de pensamento" já justifica nela mesma uma pauta específica da sociologia econômica e das finanças.

10 Não por acaso, seguindo um esquema já identificado em outras disputas de sentido sobre o significado de escândalos que agitaram os Estados Unidos, nos quais os conservadores vêem no episódio uma confirmação de que "o sistema funciona" e os contestadores justamente o contrário (Schudson, 1992).

11 Lordon (2002) analisa em profundidade um caso rumoroso que agitou a França no final do século $\mathrm{XX}$. Os dirigentes dos três principais bancos franceses, advogados intransigentes do modelo anglosaxão de capitalismo em terras gaulesas, se digladiaram até a "morte simbólica" pela incorporação e controle de cada uma daquelas instituições por uma das outras, variando ad hoc a retórica para a justificação de seus atos, mostrando assim o papel contingente e materialmente interessado de seus engajamentos doutrinários.

12 Podemos encontrar análises sobre o papel da crítica externa na evolução da legislação econômica e societária norte-americanas em Davis (1994) e McAdam et al. (1996). Uma reflexão mais geral sobre a capacidade do capitalismo contemporâneo absorver a crítica e transformá-la em fonte de novos avanços em Boltanski e Chiapello (1999).

13 Exceções interessantes têm aparecido, embora elas sejam muito ambíguas, pois expressam tentativas de diferenciação interna do campo financeiro. O caso do financista-filósofo Georges Soros talvez seja o mais interessante na esfera internacional. Uma explicação sociológica para as atividades de crítica e filantropia do personagem encontra-se em Guilhot (2004). Há também um gênero de literatura sutil de exaltação das virtudes dos mercados financeiros e de seus personagens, voltado para aqueles que não são seus apoiadores automáticos. O exemplo mais bem acabado, e interessante, é Bernstein (1992). Uma tentativa francesa, de uma editora que normalmente publica literatura crítica, denotando os propósitos da edição é Brender (2004). Em todos esses casos, é flagrante o esforço de melhorar a imagem do mundo financeiro para o resto da população, revestindo os antigos argumentos que lhe deram legitimidade o passado.

14 Refiro-me ao papel de Zola no caso Dreyfus e à análise do nascimento da figura do intelectual moderno que Charle (1990) faz a partir desse papel.

15 Nas palavras de Betinho: "A idéia do Balanço Social é demonstrar quantitativamente e qualitativamente o papel desempenhado pelas empresas no plano social, tanto internamente quanto na sua atuação na comunidade. Os itens dessa verificação são vários: educação, saúde, atenção à mulher, atuação na preservação do meio ambiente, melhoria na qualidade de vida e de trabalho de seus empregados, apoio a projetos comunitários visando à erradicação da pobreza, geração de renda e de novos postos de trabalho. O campo é vasto e várias empresas já estão trilhando esse caminho. Realizar o Balanço Social significa uma grande contribuição para consolidação de uma sociedade verdadeiramente democrática". Ver o endereço eletrônico: http://www.balancosocial.org.br/cgi/cgilua.exe/sys/start.htm.

16 Ver http://wbln0018.worldbank.org/EURVP/ web.nsf/0/18468e07bba72e55c1256bde005d40b0? OpenDocument

17 Sobre a polêmica em torno da fundação do Fórum Social, ver Eichenberg (2003), no endereço: http://www1.folha.uol.com.br/folha/mundo/ ult94u65520.shtml.

18 Sobre o esvaziamento da crítica operária, ver, além de Boltanski e Chiapello (1999), o interessante texto de Beaud e Pialoux (1999).

19 E referendando a análise, cumpre notar que per- 
guntas sobre "Onde está o espírito de Porto Alegre?" têm sido freqüentes em exposições recentes que tenho feito sobre a "financeirização" do capitalismo brasileiro sob a batuta petista, tanto em solo francês como norte-americano. E, não por acaso, sugeriram a redação desse segmento do texto.

20 Ver http://www.cebds.org.br/cebds/, do Conselho Empresarial Brasileiro para o Desenvolvimento Sustentável (CEBDS), entidade criada em 1997, congregando muitas das grandes empresas atuantes no Brasil e, de alguma maneira, tentando ordenar o debate sobre o significado da "sustentabilidade" a partir de discussões patrocinadas por esse grupo de interessados.

21 Por exemplo, as conseqüências de um acidente equivalente ao de Bhopal, na Índia, se acontecesse num país desenvolvido, ou uma hipotética, mas não impossível, sentença judicial definitiva, caracterizando que os cânceres de pulmão e outras afecções devem-se ao consumo de cigarros e que as empresas fabricantes devem ser responsabilizadas seja pelos tratamentos dos doentes, seja pela interrupção das suas vidas profissionais, seja pelos custos adicionais nos sistemas de saúde causados pelo uso do tabaco.

22 A nossa "governança familiar" aparece na mídia como um instrumento para preservar as fortunas das famílias dos proprietários de empresas dos azares dos processos de sucessão geracional. É interessante que esse problema poderia ser resolvido de outra maneira, através da importação dos trusting funds, um instrumento já tradicional na paisagem do direito norte-americano, que impacta as famílias e a sociedade de maneira bem diferente. Ele induz as famílias a se retirarem completamente dos negócios em troca de maior segurança na perenidade da riqueza herdada e direciona às necessidades da sociedade uma boa parte daquele montante (Marcus e Hall, 1992). E a própria questão geral da governança corporativa norte-americana tem essa origem: os agentes fiduciários (trustees) encarregados de gerir os patrimônios familiares são induzidos a diversificar os investimentos em um portfólio no qual o peso das ações da companhia que originou a fortuna familiar vai progressivamente diminuindo em prol da pulverização dos riscos em uma grande quantidade de aplicações cujos resultados devem ser o mais independentes uns dos outros, reduzindo drasticamente a possibilidade de um empobrecimento. Diante desse constrangimento, é altamente não recomendável que um portfólio carregue quantidade excessiva de uma só aplicação, inclusive (e principalmente) aquela efetuada no negócio que deu origem à fortuna da família.

23 Aferi um fenômeno análogo ao me deparar com a dificuldade de transmissão geracional em dinastias de calçadistas de origem armênia na cidade de São Paulo no início da década de 1990 (Grün, 1992). Naquele momento, justamente não havia nenhuma linguagem legítima para expressar o descontentamento das candidatas a herdeiras preteridas, e o resultado era o desarranjo das sucessões com o conseqüente esmaecimento do cluster étnico.

24 Ver, entre outras, a proposta patrocinada pelo Instituto Brasileiro de Governança Corporativa (IBGC) em http://www.ibgovernança corporativa.org. br/ibConteudo.asp?IDArea $=848 \&$ IDp $=846$.

25 Análises gerais sobre a difusão de "modas" organizacionais em Cole (1989; 1999) e em Nohria e Eccles (1992).

26 É interessante notar que a maior parte dos analistas da governança corporativa (Jackson, 2001; Guillén, 2000; Streeck, 2001) vêm da tradição de estudo dos modelos de capitalismo, de origem disciplinar na Economia Política ou na Ciência Política, ambas de corte macrossocial, o que provavelmente os torna pouco propensos a notar as questões microorganizacionais.

27 Nesse sentido, é interessante notar a impugnação sofrida por uma extensa e interessantíssima reportagem recente na Economist questionando a idéia de responsabilidade social empresarial (Crook, 2005). O arauto do liberalismo internacional questiona a idéia em termos da sua lógica na sociedade, mas acaba se rendendo às evidências de que o conceito ganhou cidadania e parece ter vindo para fi- 
car. Um conjunto de críticas ao seu ponto de vista pode ser encontrado no próprio site da revista: http://www.economist.com/surveys/displaystory.cfm?story_id=3574392.

\section{BIBLIOGRAFIA}

ABRAPP. Associação Brasileira das Entidades Fechadas de Previdência Complementar (2004), Consolidado estatístico. São Paulo, Abrapp, mar.

AGESTADO (2000), "Trabalhador poderá fiscalizar fundo de pensão". Agestado, acessado em 4 dez.

(2000), "Kandir admite alterações na lei das S.A.s". Agestado, acessado em 20 jul.

AGLIETTA, M. \& ORLÉAN, A. (2002), La monnaie entre violence et confiance. Paris, O. Jacob.

AglietTA, M. \& REBÉRIOUX, A. (2004), Dérives du capitalisme financier. Paris, Albin Michel.

ANAYA, V. D. E. M. (2002), "Mudanças no Pão de Açúcar começam em março". O Estado de São Paulo, São Paulo, 12 dez.

ARMSTRONG, P. (2002), "The costs of acitivity-based management". Accounting, Organizations and Society, 27 (12): 99-120.

BALARIN, R. (2004), "Previ critica ação da CVM em processos: Fundo, que votou contra união da Ambev com a Interbrew, cobra mais rapidez nas investigações". $\mathrm{Va}$ lor Econômico, São Paulo, 20 maio.

BARROS, G. (2004), "Indicado para presidir comissão defende rapidez a casos mais relevantes e diz ser difícil punir 'informação privilegiada'“. Folha de S. Paulo, B7, 10 abr.

BATISTA, R. (2003), "Lula defende expansão da poupança pela via dos fundos de pen- são". Valor Econômico, São Paulo, 29 maio.

BEAUD, S. \& PIALOUX, M. (1999), Retour sur la condition ouvrière: enquête aux usines Peugeot de Sochaux-Montbéliard. Paris, Fayard.

BERNSTEIN, P. L. (1992), Capital ideas: the improbable origins of modern Wall Street. New York, Free Press; Toronto, Maxwell Macmillan Canada, Maxwell Macmillan International, vol. XI.

BIRNBAUM, Pierre. (1979), Le peuple et le Gros: bistoire d'un mythe. Paris, Grasset.

BLAIR, M. M. (2003a), Reforming corporate governance: what history can teach us. Georgetown, Georgetown University Law Center (Research Paper, 485.663).

. (2003b), "Shareholder value, corporate governance and corporate performance: a post-Enron reassessment of the conventional wisdom", in P. K. C. A. B. Kogut (ed.). Corporate governance and capital flows in a global economy, Oxford, Oxford University Press.

BOLTANSKI, L. \& CHIAPELLO, E. (1999), Le nouvel esprit du capitalisme. Paris, Gallimard (NRF essais).

BOURDIEU, P. (1974), "Avenir de classe et causalité du probable". Revue Française de Sociologie, 1 (15): 3-42, jan.-mar.

(1989), La noblesse d'état: grandes écoles et esprit de corps. Paris, Minuit (Sens commun).

(1997), Méditations pascaliennes. Paris, Seuil.

BOYER, R. (2002), La croissance début de siáecle: de l'octet au géne. Paris, A. Michel (Bibliothéque Albin Michel. Economie).

BRENDER, A. (2004), La France face aux marchés financiers. Paris, La Découverte (Repères. Thèses et débats, 385). 
CAMBA, D. (2005), "O que é ser socialmente responsável? Entidades e empresas travam batalha para definir critérios que deixariam ações de fora do Índice de Sustentabilidade em preparação pela bolsa". Valor Econômico, São Paulo, 30 mar.

CARVAlHO, M. C. (2004a), "Princípios do Equador: banco é o terceiro do Brasil a aplicar critérios da IFC na avaliação de grandes projetos - Bradesco adota novos critérios socioambientais". Valor Econômico, São Paulo, 9 set.

(2004b), "Sustentabilidade: relatório apóia microcrédito, financiamento de projetos socioambientais e fundos éticos; ABN AMRO destaca iniciativas brasileiras". Valor Econômico, São Paulo, 20 set.

CHESNAIS, F. (2004), La finance mondialisée: racines sociales et politiques, configuration, conséquences. Paris, La Découverte (Textes à L'Appui. Série Economie).

COLE, R. E. (1989), Strategies for learning: smallgroup activities in American, Japanese, and Swedish industry. Berkeley, University of California Press, vol. XVI.

. (1999), Managing quality fads: how American business learned to play the quality game. Nova York, Oxford University Press, vol. VIII.

CROOK, C. (2005), "Survey: corporate social responsibility The good company. The movement for corporate social responsibility has won the battle of ideas. That is a pity". The Economist, 20 Jan.

DAVIS, G. F. \& THOMPSON, T. A. (1994), "A social movement perspective on corporate control". Administrative Science Quarterly, Ithaca, 39 (1): 141-173.

DEZALAY, Y. G. B. (2002), The internationalization of palace wars: lawyers, economists, and the contest to transform Latin American States. Chicago, University of Chicago Press.
DONADONE, J. C. \& GRÜN, R. (2001), "Participação é necessária! Mas como?", Revista Brasileira de Ciências Sociais, 16 (47): 111-126, out.

DOUGLAS, M. (1996), Thought styles: critical essays on good taste. London, Thousand Oaks; California, Sage, vol. XVII.

DRUCKER, P. F. (1976), The unseen revolution: how pension fund socialism came to America. Londres, Heinemann, vol. 7.

ECCLES, R. G. et al. (1992), "Beyond the hype: rediscovering the essence of management". Boston, MA, Harvard Business School Press, vol. XIV.

EICHENBERG, F. (2003), "Paternidade do Fórum Social gera disputa". Folha de S. Paulo, 14 nov.

FAMA, E. F. (1980), "Agency problems and the theory of firm". Journal of Political Economy, 88 (2): 288-307.

FLIGSTEIN, N. (2001), The architecture of markets: an economic sociology of twenty-firstcentury capitalist societies. Princeton, Princeton University Press, vol. XIV.

FLIGSTEIN, N. \& FRIEDLAND, R. (1995), "Theoretical and comparative perspectives on corporate governance". Annual Review of Sociology, p. 21-43.

FROUD, W. C. H. et al. (2000), "Financialisation and shareholder value: consultancy moves, management promises". Economy and Society, 29 (1): 80-120.

GATES, M. N. (2003), "The Sarbanes-Oxley Acr and non-US issuers: considerations for international companies". Journal of Commercial Biotechnology, 10 (1): 40-53.

GOODMAN, N. (1978), Ways of worldmaking. Indianapolis, Hackett, vol. X.

GRÜN, R. (1992), Negócios E famílias: armênios em São Paulo. São Paulo, Idesp, Editora Sumaré (Série Imigração). 
. (2003), "Atores e ações na construção da governança corporativa brasileira". Revista Brasileira de Ciências Sociais, 18 (52): 121-143.

. (2003), "Fundos de pensão no Brasil do final do século XX: guerra cultural, modelos de capitalismo e os destinos das classes médias". Mana, 9 (2): 7-38, out.

. (2004a), "A evolução recente do espaço financeiro no Brasil e alguns reflexos na cena política". Dados, 47 (1): 5-47.

. (2004b), "A sociologia das finanças e a nova geografia do poder no Brasil".

Tempo Social, 16 (2) : 151-176.

GUILHOT, N. (2004), "Une vocation philanthropique. Georges Soros, les sciences sociales et la régulation du marché mondial". Actes de la Recherche en Sciences Sociales, 151-2: 36-48.

GUILLEN, M. (2000), "Corporate governance and globalization: is there convergence across countries?", Advances in Comparative International Management, 13: 175-204.

HACKING, I. (2003), "Inaugural lecture: chair of philosophy and history of scientific concepts at the Collège de France, $16 \mathrm{Ja}$ nuary 2001". Economy and Society, 31 (1): $1-14$.

. (2004), "Between Michel Foucault and Erving Goffman: between discourse in the abstract and face-to-face interaction". Economy and Society, 33 (3): 277-302.

HUCZYNSKI, A. (1993), Management gurus: what makes them and how to become one. Londres, Routledge.

JACKSON, H. (2001), "An emerging market for corporate control? The Mannesmann takeover and German corporate governance", Max Planck Institute for the Development of Societies, Köln, Sept. (Discussion Paper).
KÊNIA, M. (2002), "Fique atento, defenda o que é seu: family offices podem ajudá-lo na tarefa". Istoé Dinheiro, 4 jan.

$\mathrm{KOCH}, \mathrm{C}$. (2001), "Enterprise resource planning: Information technology as a steamroller for management politics?", Journal of Organizational Change Management, 14 (1): 64-78.

KOONTZ, H. \& O'DONNELL. C. (1962), Princípios da administração: uma análise das funções administrativas. São Paulo, Editora Pioneira.

LANE, C. (2003), "Changes in corporate governance of German corporations: convergence to the Anglo-American model?", Competition and Change, 7 (2-3): 79100, jun.-sept.

LORDON, F. (2000a), Fonds de pension, piége à cons? Mirage de la démocratie actionnariale. Paris, Raisons d'Agir.

. (2000b), "La 'création de valeur' comme rhétorique et comme pratique. Généalogie et sociologie de la 'valeur actionnariale'. L'Année de la régulation: Économie, Institutions, Pouvoirs, 4: 117-70.

. (2002), La politique du capital. Paris, Odile Jacob.

MACKENZIE, D. (2003), "Long-term capital management and the sociology of arbitrage". Economy and Society, 32 (3): 349-80, aug.

MACKENZIE, D. \& MILLO, Y. (2003), "Constructing a market, performing theory: the historical sociology of a financial derivatives exchange". American Journal of Sociology, 109 (1):107-45.

MANOFF, R. K. \& SCHUDSON, M. (1986), Reading the news: a pantheon guide to popular culture. Nova York, Pantheon Books.

MARCUS, G. E. \& HALL, P. D. (1992), Lives in trust: the fortunes of dynastic families in late twentieth-century America. Boul- 
der, Westview Press, vol. IX (Institutional Structures of Feeling).

MARTINS, L. (1976), Pouvoir et développement économique: formation et évolution des structures politiques au Brésil. Paris, Anthropos.

MARX, K. \& ENGELS, F. (1950), Misère de la philosophie, en réponse a la philosophie de la misere de M. Proudhon. Paris, A Costes, vol. XXXVII.

MATTOS, M. (2001), "Lei das S.A. é aprovada e já se negociam vetos à proteção de minoritários". Valor Econômico, São Paulo, 20 set.

McADAM, D. et al. (1996), Comparative perspectives on social movements: political opportunities, mobilizing structures, and cultural framings. Cambridge, England/ Nova York, Cambridge University Press, vol. XIV (Cambridge Studies in Comparative Politics).

MELLO, E. C. D. (1995), A fronda dos mazombos: nobres contra mascates, Pernambuco, 1666-1715. São Paulo, Companhia das Letras.

MICHAEL, I. D. A. (2004), "Kroll tinha fortes ligações com a área policial, diz PF". Folha de S. Paulo, A11, 4 ago.

MIGNONE, R. (2003), "Saída de Grajew não foi motivada por divergências, diz Dirceu". Folha de S. Paulo, 11 nov.

MOTTA, F. C. P. (1968), O racionalismo capitalista e a evolução da empresa brasileira. Dissertação de mestrado, São Paulo, Escola de Administração de Empresas de São Paulo.

MURPHY, P. (2002), "Esquerda e Bovespa fazem aliança estratégica: para presidente da Bolsa, 'muro de Berlim caiu' com a inédita visita de Lula ao pregão". O Estado de São Paulo, 1 set.
NOHRIA, N. \& ECCLES, R. G. (1992), Networks and organizations: structure, form, and action. Boston, MA, Harvard Business School Press, vol. XVI.

NORONHA, E. G.; GEBRIN, V. \& ELIAS JR., J. (no prelo), "Explaining an exceptional wave of strikes: from authoritarian Brazil to democracy". British Journal of Industrial Relations.

NORREKLIT, H. (2000), "The balance on the balanced scorecard: a critical analysis of some of its assumptions". Management Accounting Research, 11: 65-88.

NORTH, D. C. (1990), Institutions, institutional change, and economic performance. Cambridge/Nova York, Cambridge University Press, vol. VIII (The Political Economy of Institutions and Decisions).

ORLEAN, A. (1999), Le pouvoir de la finance. Paris, O. Jacob.

PAVINI, A. (2004), "Bovespa quer atrair mais empresas e aplicadores em ações: Estratégia inclui mercado de acesso, pedido de linha para o BNDES e atuação nas embaixadas". Valor Econômico, São Paulo, 27 jul.

POLANYI, K. (2001 [1944]), The great transformation: the political and economic origins of our time. Boston, MA, Beacon Press, vol. XLI.

POWELL, W. W. (2001), "The capitalist firm in the twenty-first-century: emerging patterns in western enterprise", in P. Dimaggio (ed.), The twenty-first-century firm: changing economic organization in international perspective. Princeton, Princeton University Press, vol. VIII, 275, pp. 33-67.

RIPARDO, S. (2002), “Projeto Bovespa-Lula' reedita propostas do plano diretor de abril". Folha Online, acessado em 1 out. 
ROE, M. J. (1992), Some differences in corporate governance in Germany, Japan and America. Nova York, NY, Center for Law and Economic Studies Columbia University School of Law.

(1994), Strong managers, weak owners: the political roots of American corporate finance. Princeton, NJ, Princeton University Press, vol. XVI.

ROSSI, C. (2003), "Lula leva proposta de pacto social a Davos". Folha de S. Paulo, 23 jan.

SCHUDSON, M. (1992), Watergate in American memory: how we remember, forget, and reconstruct the past. New York, Basic Books, vol. XII.

SCHUMPETER, J. A. (1991), The economics and sociology of capitalism. Princeton, NJ, Princeton University Press.

STERNHELL, Z. (1997), La droite révolutionnaire: Les origines françaises du facisme 18851914. Paris, Gallimard.

. (1994), L'Éternel retour: contre la démocratie, l'idéologie de la décadence. Paris, Presses de la Fondation Nationale des Sciences Politiques.

STREECK, W. (2001), "La transformation de l'organisation de l'entreprise en Europe: Une vue d'ensemble", in R. M. Solow (ed.), Institutions et croissance: Les chances d'un modèle économique européen, $\mathrm{Pa}$ ris, Albin Michel, pp. 175-230.

USEEM, M. (1993), Executive defense: shareholder power and corporate reorganization. Cambridge, MA, Harvard University Press, vol. XI.

. (1996), Investor capitalism: how money managers are changing the face of corporate America. Nova York, Basic Books, vol. VIII.

VALOR ECONÔMICO. (2003), "Oded Grajew pede afastamento do governo e quer virar co- laborador". Valor Econômico, São Paulo, 11 nov.

(2002), "Grupo Votorantim projeta crescer 20\%". Valor Econômico, São Paulo, $15 \mathrm{fev}$.

. (2001), "Terceira geração da família Ermírio de Moraes já comanda o Votorantim”. Valor Econômico, São Paulo, 31 ago.

VIEIRA, C. (2004), "Calpers deve investir em imóveis no Brasil". Valor Econômico, São Paulo, 9 jul.

(2004), "Especialista critica falta de transparência das teles. William Cox, especialista em governança corporativa nos EUA: bons exemplos são os da Embraer e da Ambev. Valor Econômico, São Paulo, 9 out.

WAKSMAN, H. (1997), "Os fundos de pensão e a imunidade fiscal". Folha de S. Paulo, 2/2, 9 nov.

WALSH, M. W. (2002), "Calpers Wears a Party, or Union, Label". The New York Times, 13 Oct.

WEBER, M. (1987 [1898]), La Bolsa: introducción al sistema bursátil. Barcelona, Ariel. 


\section{CONVERGÊNCIA DAS ELITES E INOVAÇÕES FINANCEIRAS: A GOVERNANÇA CORPORATI- VA NO BRASIL}

\author{
Roberto Grün
}

\section{Palavras-chave}

Sociologia econômica; Sociologia das finanças; Financeirização; Governança corporativa; Convergência das elites.

A governança corporativa tem sido vista cada vez mais como o conjunto de "ferramentas" que produzem a "financeirização" da economia e da sociedade. Analisando a sua difusão no Brasil, verificamos que o preço do seu espraiamento é uma espécie de "tropicalização" e reinterpretação do seu sentido, segundo as sensibilidades e os interesses dos diversos setores das elites brasileiras - da financeira à sindical - que concorrem para a sua instalação legal e organizacional. Dessa maneira, este artigo pretende mostrar algumas ambigüidades da "financeirização à brasileira" e também o papel da linguagem financeira na criação de um espaço para a convergência e o consenso parcial de nossas elites.

\section{CONVERGENCE OF ELITES AND FINANCIAL INNOVA- TION: CORPORATIVE GOVERNANCE IN BRAZIL}

Roberto Grün

\section{Keywords}

Economical sociology; Financial sociology; "Financialisation;" Corporative governance; Convergence of elites

The Idea of Corporate Governance, North-American style, is spreading in Brazil. Apparently it's a simple isomorphic movement conducted by the financial market and Federal Government paving the way to the "financialisation" of Brazilian economy and society. Looking in depth, we can see a lot of peculiarities caused by the uses $\mathrm{f}$ the idea in the hands of ours elites. Actually, the Brazilian elites are carving a new meaning for the concept, infusing their particular interests and sensibilities. The text wants to analyze this spreading as a kind of social polysemy in a "Bourdieusian" flavor, trying to demonstrate that the Brazilian Corporate Governance is more a very plastic cultural concept than a rational economic tool.
CONVERGENCE DES ÉLITES ET INNOVATIONS FINANCIÈRES: LA GOUVERNANCE CORPORATIVE AU BRÉSIL

Roberto Grün

\section{Mots-clés}

Sociologie économique; Sociologie des finances; Financérisation; Gouvernance corporative; Convergence des élites.

La governance corporative est de plus en plus perçue comme un ensemble d'“outils" qui produisent la "financérisation" de l'économie et de la société. En étudiant sa diffusion au Brésil, nous vérifions que le prix de son irradiation est une espèce de "tropicalisation" et de reinterprétation de son sens suivant les sensibilités et les intérêts des divers secteurs des élites brésiliennes - de la financière à la syndicale - qui concourent en vue de son installation légale et organisationnelle. Cet article prétend démontrer quelques ambiguités de la "financérisation à la brésilienne" mais, aussi, le rôle du langage financier dans la création d'un espace pour une convergence et un consensus partiel de nos élites. 